\title{
The sweep of the boreal in time and space, from forest formations to genes, and implications for management ${ }^{1}$
}

\author{
by Alan G. Gordon ${ }^{2}$
}

The ranges and ancient origins down through the Pleistocene of the species which make up the Boreal Forest formation are discussed. Jack and lodgepole pine, white and black spruce are essentially modern; others are older. Genetic variation of the five major boreal species groups - poplars, birches, pines, spruces and tamarack - is outlined. A discussion of natural hybrids and introgression follows with examples of types of species pairs, and artificial hybridization in poplars, and white and black spruce. Specialized life strategies of species for growing in the boreal zone and how silvicultural systems may be related to them are explained. Understanding genetic diversity and its importance in management applications is critical for the maintenance of welladapted populations. Failure to do so results in erosion or even total loss of gene pools. Historical examples and current practices in the northeast and certain areas of the boreal forest indicate that losses in genetic diversity, reduced biodiversity, commercial and even local extinction may be widespread. It is hoped that development and application of as yet proximal forest genetic management principles will enable the maintenance of the forests' genetic structures and gene pools, critical for the true sustainablity of forest ecosystems.

Key words: boreal, biogeography, genetic variation and diversity, hybrids, inbreeding, life strategies, silvicultural systems, future

\section{Introduction}

The Boreal Forest of North America and the Northern Taiga of Eurasia are a circumpolar forest formation. Compared to the rain forest, the boreal forest may seem like a simple formation. In North America there are just a dozen species more or less: white and black spruce, jack and a little lodgepole pine, balsam and some small areas of subalpine fir, eastern white cedar, tamarack, trembling aspen, balsam poplar, white birch, speckled and mountain alder and black ash. However, when the tremendous environmental arrays of the Boreal Zone are considered, together with the multitude of adaptive strategies developed within these species for growing in environments with harsh northern climates, the boreal forest no longer seems so simple.

\footnotetext{
${ }^{1}$ A paper presented at "Ecology and Siliviculture of the North American Northern/Boreal Forest: Understanding the Past and Charting the Future." Session at the CIF and SAF Joint Annual Meeting held at Anchorage, Alaska, on 18-22 September 1994

${ }^{2}$ Ontario Forest Research Institute, P.O. Box 969, Sault Ste. Marie, Ontario,
} Canada P6A 5N5.
Cet article discute de la distribution et des origines à compter du Pléistocène des espèces qui ont composé la forêt boréale. Les pins gris et tordus et les épinettes blanches et noires sont essentiellement des espèces modernes, les autres étant plus anciennes. La variation génétique des cinq principaux groupes d'espèces boréales, les peupliers, les bouleaux, les pins, les épinettes et les mélèzes, est soulignée. Une discussion sur les hybrides naturels et l'introgression suit ainsi que des exemples de paires typiques au niveau des espèces et d'hybridation artificielle chez les peupliers, et l'épinette blanche et noire. Les stratégies de croissance spécialisées permettant un développement dans la zone boréale et les régimes sylvicoles pouvant y être reliés sont expliqueés. La compréhension de la diversité génétique et de son importance au niveau des applications en aménagement est primordiale au maintien des populations bien adaptées. Dans le cas contraire, il en résulte une érosion ou une perte complète des pools génétiques. Les exemples historiques et les pratiques actuelles que l'on retrouve dans le nord-est et dans certaines régions de la forêt boréale, démontrent que les pertes au niveau de la diversité génétique, la réduction de la biodiversité et l'extinction commerciale et même locale sont peut être fréquentes. Il est à espérer que le développement et l'application des tout prochains principes de génétique forestière en aménagement permettront de maintenir les structures et les pools génétiques des forêts, éléments essentiels pour la durabilitié des écosystèmes forestiers.

Mots clés: boréal, biogéographie, diversité et variation génétique, hybrides, croisement, stratégies de croissance, régimes sylvicoles, avenir

\section{Ranges}

In North America, the range of the genus Pinus reaches its northern limit with only two species, the essentially boreal jack pine and the Cordilleran lodgepole pine. Together they occupy about two thirds of the Boreal Zone. Their presence is matched in the northern Taiga of Eurasia by Scots pine which is both a temperate and a boreal species, and, occupying $125^{\circ}$ of longitude, has the widest continuous range of any arboreal species (Critchfield and Little 1966). It is only exceeded by the circumpolar common juniper, which has the largest range of any tree or shrub species in the world (Dallimore and Jackson 1948).

The ranges of the five principal boreal species, however, are truly remarkable. Trembling aspen, balsam poplar, white birch and white and black spruce extend across the breadth of the continent at its maximum width. They have the largest continuous ranges, $107^{\circ}$ of longitude, save for the aforementioned Scots pine and common juniper, of any species in the world. Tamarack, or eastern larch, also has an extensive range in the boreal forest but it is very restricted in Alaska and almost absent in the Yukon. Eurasian species, for the most part, commonly have more restricted or discontinuous ranges as is the case with the three northern larch species, European, Siberian 
and Dahurian larches, (Tikhomirov pers.com. 1959). Black spruce, with its extremely high density per unit area, is probably the most numerically common arboreal species on earth.

\section{Origins and Biogeographic History: Where did These Species Come From?}

When the fossil record and numbers of species within various taxonomic groupings are examined, it is possible to ascertain continental centres of species radiation. All four genera, Populus, Betula, Pinus and Picea are circumpolar in their fossil representation. From this it can be deduced that their initial generic or even species evolution occurred before the continents pulled apart. Both balsam poplar and trembling aspen have been present in western North America for a long time. Generic and occasionally species equivalents indicate that the forebears of balsam poplar were present in the late Eocene, 38 million years before the present (yr BP) (Becker 1973). Those of trembling aspen existed in the Miocene, 5-25 million yr BP (Knowlton 1898; Becker 1973). Although "birch" is known from the Oligocene, the specific fossil equivalent of white birch is well represented later, from the mid Miocene, 15 million yr BP (Graham 1965). The progenitors of our modern pine species are much older. Different sub-groups appeared in the early and late Cretaceous, 136 to 65 million yr BP, and many species equivalents are known from the Tertiary, 60 million yr BP, to the modern forests of the Pliocene, 5-2 million yr BP. However, jack pine and lodgepole pine appear to be relatively modern. No known fossil equivalents of these species have been identified thus far in pre-Pliocene strata. This, incidentally, is much in agreement with Dancik and Yeh (1983) who, using the average genetic distance between jackpine and lodgepole pine, estimated the approximate date when these species diverged from one another as 485 to 565 thousand yr BP.

Fossil evidence suggests that spruce or spruce-like trees apparently were already widespread in the late Cretaceous, pre 65 million yr BP, from northern Japan and eastern North America (Florin 1963). They became much more common through the following Tertiary epochs: Paleocene, Eocene, Oligocene and Miocene and continued to develop into the modern forests of the Pliocene, 5-2 million yr BP.

Two fossil spruce species are of interest in relation to modern boreal species. Picea lahontense is the non-boreal fossil equivalent of the non-boreal Engelmann spruce of mid latitude Rocky Mountains. Its seeds are identical to those of $P$. engelmannii and they probably are the same species. $P$. lahontense fossils date from the early Oligocene about 35 million yr BP (MacGinitie 1953) and the species became widespread through the Miocene, 25-5 million yr BP and into the early Pliocene (Axelrod 1944) where it is essentially modern. Engelmann spruce is not the progenitor of white spruce, which is a recent, boreal species. They are genetically related, however, and freely interbreed on contact.

A second species, P. banksii (Hills and Ogilvie 1970) from the late Miocene in the Canadian Arctic may have been associated with the evolution of white spruce. It has cones, however, which are larger and different from those of white spruce, but its fossil associates, hemlock, birch, willow, maple, hickory, hazel, fir, elm, white pine etc., are similar to those of white spruce in eastern North American forests today.

Heimburger (1984) considered black spruce to be a relatively young species with its origins entirely in North America. He notes there is no trace of it in Asia. Until recently the two earliest fossil records were Pleistocene from the preglacial Wisconsin and from one of the interglacials (Brubaker 1983). However, Hopkins et al. (1971) had reported good megafossils of black spruce along with those of white spruce and other species from a rich coniferous forest from the early Pliocene farther west than the extreme western limit of its present range in Alaska. Heimburger (1984) suggested a hybrid origin of this species after considering the abundance of available hybrid habitat in a late pre-Wisconsin interglacial, the edaphic restriction (low-lime) of black spruce, and the interspecific breeding work of Gordon (1980).

During the late Oligocene to middle Miocene a mixed mesophytic forest formation extended from Japan, central and southern China through eastern Siberia and Beringia (the Bering Land Bridge) into Alaska. This forest was primarily hardwoods and included many species that are conspecific today in eastern North America and eastern and central China. In addition there were some conifers: spruce, fir, hemlock, pines mostly at high elevation, and dawn redwood. Spruce was also present in coastal areas. Gradual cooling from the mid to late Miocene resulted in high latitude extinctions of many temperate hardwood species and some but not all cool temperate conifers in Alaska, Beringia and eastern Siberia. The mixed mesophytic forest bridge between the two continents was broken. The same cooling conditions in the late Miocene, while not yet an extreme boreal climate, separated the cool temperate conifer forests of both continents before any migration or exchange of modern tree species could take place. At this time the Bering Straight opened and conditions became more boreal. Two great separate but synonymous and continuous conifer forests came into existence, one extending from Japan and northeast China, Kamchatka northeasterly up into Siberia, and the other extending from Alaska, down through British Columbia into Oregon (Wolfe and Leopold 1967).

During the Pleistocene, (2 million to 10,000 yr BP) while all of Canada (except for a fragment of southeast Alberta) was covered at maximum glaciation of the Wisconsin $(18,000 \mathrm{yr}$ $\mathrm{BP}$ ) by an ice sheet, most of Alaska was ice-free and Beringia was once again opened for thousands of years. The climate for forest migration, however, was forbidding. All through the Pleistocene many tundra/steppe shrub species, herbaceous plants, grasses and mosses commonly shared Siberia, Beringia and Alaska, and, except for the presently submerged Beringia, continue to do so today. These same plant species today characterize forest-tundra ecotones with comparable but distinctly Asian and North American tree species on their respective continents (Tikhomirov 1959).

Although Wolfe and Leopold (1967) argue persuasively that the floristic histories of northeastern Siberia and Alaska are essentially one and the same, and that as time went on in the Miocene, conditions on the Beringian land bridge became suboptimal for the growth of tree species, it is tempting to think that some modern tree species from the Pliocene/Pliestocene and Recent epochs, 5 million years ago to the present, may also share these land masses. Indeed there are none but some are close. Larix dahurica of eastern Siberia is quite similar to L. laricina of Alaska, and Picea sitchensis of coastal Alaska is quite similar to $P$. jezoensis of Japan and Kamchatka, and there are some similarities among the alders. The most modern forms of these species today, however, are considered to be distinct species. 
The birch species that today do share these lands on both sides of the Bering Strait are non-arboreal shrub species. There are no pines in Alaska (except lodgepole or shore pine, far south on the non-boreal panhandle) or anywhere in northeastern Siberia. Black and white spruce are common and widespread in Alaska, essentially to the west coast, north of the Seward Penninsula, but there are no spruce in eastern Siberia, a gap of $52^{\circ}$ of longitude (north of $60^{\circ}$ lat.). The nearest Asian spruces are Yeddo spruce (Picea jezoensis) in an outlier in Kamchatka much farther south and west; and Siberian spruce ( $P$. obovata) in an outlier in Magadan, even farther west. The ranges of the Asiatic and North American larches approach one another more closely than do those of the spruces, with a separation of $29^{\circ}$ longitude (north of $60^{\circ}$ lat.). Dahurian larch (Larix gmelini) extends farther east in northeastern Siberia than does spruce, and tamarack (eastern larch) although much more restricted in Alaska than spruce, extends almost as far west as does spruce.

So, there are no Asian tree species in North America and no North American tree species in Asia. This tells us something about the evolutionary ages of our own boreal species. White and black spruce, jack and lodgepole pine are essentially modern, extending well back through the Pleistocene 2 million years, but no farther back than the Pliocene, 2-5 million yr BP. This is in accord with the fossil record. There are as yet no pre-Pliocene fossils of these four species, although Pleistocene relicts are common. Some other species among the birches, poplars and firs, as noted previously, have fossil equivalents from earlier times.

\section{The Closing of the Pleistocene: Recovering Lost Ground}

Palynological information on the postglacial migration and re-establishment of the forest has been exquisitely synthesized for eastern North America by Delcourt and Delcourt (1987) and for Canada by Ritchie (1987). Löve (1959) however, from phytosociological data was the first to show that there was a separation of eastern and western components of floristic associates of white spruce. The 'eastern boreal element' migrated northwards from the Great Lakes into eastern Manitoba and northwards, whereas the 'western boreal element' invaded Manitoba from the west. A few of this latter element reached as far east as James Bay.

Using data from white spruce provenance studies, Holst (1960) demonstrated the possibility of two south-to-north genetic clines in white spruce, one to the east of the Ottawa Valley and one to the west. Nienstaedt (1969), using further white spruce provenance material, demonstrated the southeastern distribution of white spruce was a two-pronged genetic cline, extending into northwestern Canada on the west side of Hudson's Bay, and to Labrador on the east. Wilkinson et al. (1971), utilizing cortical oleoresin monoterpene composition of white spruce, showed that there were indeed distinct northeastern and northwestern white spruce populations. The primary population axes were up the Manitoba-Ontario boundary to the northwest, and northeasterly to Labrador, confirming the work of both Löve (1959) and Nienstaedt (1969). He also located a secondary division from the southeast up the Ottawa Valley, confirming the findings of Holst (1960). The paleo-dominance information provided by Delcourt and Delcourt (1987) from 14,000 yr BP through 12,$000 ; 10,000$ and 8,000 yr BP provides remarkable confirmation of these findings.
At the beginning of the retreat of the Laurentide and the Cordilleran ice sheets from the central and western part of the continent, white spruce and most probably all its boreal associates moved northward from the Great Plains, initially invading treeless vegetation at the ice front (Ritchie 1987). The astonishingly rapid northward movement through Canada from southern Alberta, about 10,000 yr BP, of white spruce, with intervening grassland associates, and the mechanism of how this occurred have been documented by Ritchie and MacDonald (1986). This advance initially into, and westward across Alaska from about 9,000 to $5,000 \mathrm{yr}$ BP for white spruce, and 7,000 to $6,000 \mathrm{yr}$ BP for black spruce, to western Alaska and to southwestern Alaska by $4,000 \mathrm{yr}$ BP has been presented by Brubaker (1994).

Current interpretation supports the view that no coniferous species survived in ice-free Alaska at full glaciation. There is support that some hardwood species may have survived; and that balsam poplar did make an early appearance. Black spruce is enigmatic. Its tolerances are quite different from those of white spruce. It is absent from vast areas in the west in which white spruce is common and widely distributed (Heimburger 1984) and seems unable to grow on calcareous substrate unless it is shielded from it by an accumulation of acidic organic material, such as the peat lands in the James Bay lowlands. This may account for its later arrival. Being more tolerant of colder substrates than white spruce, and able to grow over permafrost (Viereck et al. 1983), provide room for argument that black spruce could also have survived in ice-free Alaska, yet in numbers insufficient to provide easily recoverable megafossils. Its colonization of open land from small refugial pockets could also be much slower than white spruce, particularly if available lime in the soils was high.

\section{Genetic Variation in the Boreal}

A wide array of techniques has been used in the studies of variation in trees and other plants. Initially descriptive morphology was used widely, and is still useful. Studies of growth and other physiological and ecological attributes as well as breeding affinities, followed closely studies of monoterpene chemistry (particularly useful in Pinus) and phenolic, flavonoid and stillbene chemistry. In the past $15 \mathrm{yr}$ there has been a plethora of studies on the genetic structure of populations of a wide array of tree species employing isozyme chemistry. These are particularly useful since they provide allele frequencies, which are critical in the determination of genetic diversity. Most recently, mitochondrial and chloroplast DNA technologies are adding to our understanding of genetic variation. These techniques, among other attributes, can be used to delineate species and genotype identity (limits), provide maternal and paternal identity, discern discrete population structure and evaluate genetic diversity (e.g. Rajora et al. 1991; Isabel et al. 1993).

With such vast ranges, boreal species have great opportunity to exploit a wide array of environments and through natural selection have developed into well-adapted races, clines and genotypes. Variation is expressed particularly in physiological traits involving the ability to survive and reproduce in cold, wet or dry environments, and in tolerances with respect to edaphic restriction, particularly nutrient supply or toxicity, and resistance to insect damage, or disease etc. Where competition becomes a factor, variation in growth or spatial strategies involving stand densities is expressed. High 
latitude boreal species have typically slow growth, relatively small branches, good bole form and early flowering.

\section{Poplar, Birch and Balsam Fir}

Of the major boreal genera, little information has been collected on poplar or birch apart from a few regional studies in Quebec and Ontario (Beaudoin et al. 1984; Farmer and Reinholt 1986; Rajora et al. 1991). Unlike work in Scandinavia (particularly Sweden and Finland) or Russia, no range-wide, or for most areas even regional population studies, have been completed on the ubiquitous poplars (Populus balsamifera, $P$. tremuloides). Though there has been breeding work, selections have been random. Similarly the intensive work on the Scandinavian Betula for valuable wood quality, figure and grain is unmatched in North America, although there are some detailed range-wide taxonomic studies (Grant and Thompson 1975). As with poplar there is also little information on balsam fir, which exhibits some variation, is ubiquitous, easy to grow, and still easier to regenerate. Most information thus far has been collected on white and black spruce, jack and lodgepole pine. Tamarack, or eastern larch, has been studied to a limited extent. Much information and many ideas arising out of these studies on variation have been incorporated into tree improvement research and practise, but will not be reported here since they go beyond the scope of this overview.

\section{White Spruce}

Regional and range-wide experiments of white spruce populations (Nienstaedt 1969; Teich et al. 1975), have followed the pioneering work of Holst (1960), and continue to yield valuable information. As expected, given the vast expanse of latitudinal and longitudinal terrain occupied by white spruce relative to total elevational change, variation in this species is principally clinal. However, white spruce proves to have several different, major populations, as previously noted, relating to their historical distributions during and since the Pleistocene, in which these clines are apparent, but in which they are expressed at different rates. For example, in all populations, growth rate at the planting sites decreases from south to north but it does so more rapidly in eastern populations than in western provenances.

The species in general is relatively stable, with only small genotype $\times$ environment effects. As a result, population rankings remain unchanged across many test sites through time. In contrast to the simple clinal variation exhibited by black spruce, white spruce exhibits several population centroids that clearly persist as best performers over much larger areas than their native provenances, e.g. Beachburg, Swastika (Tiech et al. 1975), and Fort Francis-Kenora (Skeates and Irving 1988). Ecotypic variation is expected in extreme environments, and limestone ecotypes have received periodic attention (Tiech and Holst 1974). Unfortunately, some of the studies undertaken to investigate this phenomenon have sampled white spruce seed or seedlings from parents located on limestone but which are still well within local pollen flight distance of trees growing on nearby granite, and the converse. Because of this, the evidence for true limestone ecotypic variation is still unresolved. White spruce is phenotypically very polymorphic (Gordon 1985). There are several classic crown forms and much variation in foliage and cone colour, shape, and size. Some of this variation is more regionally expressed (Nienstaedt 1968; Gordon 1985). Phenotypic variation in white spruce was found to be only slightly associated with isozyme variation, while allelic richness was substantially less in populations of phenotypically selected individuals (Cheliak et al. 1988). The latter finding is important. For example, plus tree selection could have negatively impacted breeding programs, where conservation of gene pool variation is now known to be critical.

\section{Black Spruce}

Variation in growth and survival of black spruce has been followed with a wide series of intensive regional and rangewide provenance trials and experiments, (Morgenstern 1969, 1978; Dietrichson 1969; Khalil 1981, 1984; Corriveau and Vallée 1981; Fowler and Park 1982; Corriveau 1982; Bihun and Carter 1983; Nienstaedt 1984; Merrill et al. 1984; Boyle 1985; Park and Fowler 1988; Beaulieu et al. 1989; Morgenstern and Mullin 1990). Results indicate that variation through early stages, at least up to $15 \mathrm{yr}$, is essentially clinal (a strong correlation of growth with geographical variables). Negative correlations exist between latitude and ecological variables such as degree days $>5.5^{\circ} \mathrm{C}$, and length of growing season. Seedling heights are correlated more strongly with ecological variables than with later height measurements. At least for seedlings up to three years, height increased from 2 to $11 \%$ from the experimental mean if a seed source was moved north $1^{\circ}$ of latitude from its origin. There is a strong correlation between nursery performance and initial performance in the field, but this does not provide for safe juvenile selection since this relationship does not hold with increasing age. During early growth stages, genotype $\times$ environment interaction is unimportant despite the largely clinal variation. However, there is a decreasing correlation between height and latitude with increasing age, indicating that the predominantly clinal variation of early stages will diminish as growth components not correlated with latitude come to dominate growth patterns. Correlations between height growth and survival disappear with age, particularly from higher latitude provenances, indicating future difficulties when simultaneously selecting for height and survival in cold climates. Sources from close to the planting sites are not necessarily the best in terms of growth and survival, i.e. not always the most well-adapted. Ranking changes are still occurring at $15 \mathrm{yr}$, and in some areas, neighbouring sources exhibit radically different ranks.

As with the possibility of limestone ecotypes in white spruce, the possibility of upland and lowland ecotypes in black spruce receives persistent and recurring attention. Fowler and Mullin (1977), utilizing cone collections from 20 tree stand mixtures from five well-separated upland and five lowland sites from each of three boreal site regions, found that after five and ten years growth there were no significant differences in seedlings between upland and lowland origins. The only significant genetic differentiation was that confirming clinal variation between the three geographic locations, which incidentally, strongly supports the Ontario forest site regions as demarcated by Hills (1960).

Heimburger (1984) on this problem, noted that "total variability" was higher in swamps than in uplands. O'Reilly et al. (1985) reported an isozyme study comparing the genetic structure of paired upland and lowland seed samples of 20 trees in each of five northern black spruce populations. Upland and lowland populations were differentiated on the basis of their single locus, as well as multilocus structure. Lowland popu- 
lations were consistently more variable genetically than the upland populations, but upland populations were more genetically differentiated from each other than were those of the lowland populations.

A number of as yet unpublished studies have indicated somewhat similar results, but also suggest that there is often as much or greater within-stand variation as between stands, regardless of site. Bush and Smouse (1992) note this is the case even with wide sampling across the range of widely distributed species. It seems that the resolution of the present question could be complex. Pollination distance between such stands is critical. Population samples from swamps dotting the surface of, for example, the high upland massif east of Lake Nipigon in Ontario where prevalent upland stands also occur, could be very different from populations drawn from a vast lowland such as the James Bay Lowlands where essentially all the black spruce are truly lowland. Because of latitudinal and isotherm shifts between such areas, unfortunately, other confounding geographic variables e.g. day length etc., come into play.

\section{Jack and Lodgepole Pine}

A number of investigators have been studying range-wide and regional variation, population differentiation, introgression, differences between mature, natural regeneration and seed source plantations as well as relationships to environmental variables in jack and lodgepole pine (Illingworth 1975: Danzmann and Buchert 1982; Dancik and Yeh 1983; Beaudoin et al 1984; Klein 1984; Yeatman 1984; Ying 1984; Knowles 1985; Govindaraju and Dancik 1987; Govindaraju et al. 1989; van Niejenhuis and Parker 1991, Morris and Parker 1992; Yeh et al. 1985). In general, local sources have proved most adapted, but certain others have performed equally well in most areas. Allelic heterogeneity tests have indicated no differences between mature, natural young stands and seed zone plantations. In sympatric (range overlap) areas inter-specific chloroplast (cp)DNA polymorphisms distinguish these species. However, large range-wide sampling has now permitted the detection of large numbers of rare, novel DNA polymorphism variants, confined to a sympatric region, as well as three recombinant $\mathrm{cpDNAs}$ having restriction fragments typical of both parental species. Preliminary investigations indicate that environment markedly influences the relationship between biochemical variation and quantitative characters, as well as the degree of expression of these characters.

\section{Tamarack}

Variability in tamarack both range-wide and regional is being investigated through provenance and subsequent progeny trials, adaptive differentiation and isozyme studies (Beaudoin et al. 1984; Cheliak and Pitel 1984; Murray and Cheliak 1986; Fowler et al. 1986; Knowles et al. 1986; Joyce 1988). A great many aspects are being studied. Preliminary results indicate that there is a large amount of inter and intra-population variation within this species. Predictions are therefore favourable for tree improvement and maintenance of gene pools.

\section{Natural Hybrids: Introgression}

Several boreal species are able to hybridize with other species. With the exception of white birch (which crosses with many other species), in most of these species pairs it is with a cool temperate non-boreal species that the boreal species hybridizes. Some of these species pairs lack both genetic and/or ecological barriers and freely hybridize where their respective ranges touch or overlap. In freely hybridizing, the pollen from one species is almost as or equally acceptable to a second species as is pollen from its own species. If genetic barriers are not strong and ecological barriers are environmentally disrupted, for example, by harvesting, clearing, climate change, etc., then there is little to protect the integrity of such species. This has happened already in certain ground flora species. Through hybridizing and much backcrossing in both species' direction over many generations, gene flow from one species to another is reciprocally effected. This process is known as introgression. It is not possible to stand on the approximate boundary between the species and identify the "true" species on either side. The two species merge imperceptibly into each other. The habitats on which they survive are usually relatively steep factorial gradients e.g. from temperate, cool alpine to cold boreal, or from temperate, cool humid maritime to cold boreal. These site gradients are known as hybrid habitats. Such bands of terrain may be narrow, in which case introgression is ecologically limited, or very broad, where the numbers of introgressants are immense, so much so that some investigators would designate the intermediates as a new species. Others would designate both participating species as variants of a single species.

\section{Introgressed Species Pairs}

Examples of such species pairs are: balsam poplar and black cottonwood (Maini and Cayford 1968; Viereck and Foote 1970), where range overlap is extensive and the species cross freely; white birch and yellow birch (Barnes et al. 1974) where range overlap is extensive but hybrids are only present in certain areas; balsam fir and subalpine fir (Hunt and von Rudloff 1974; Parker et al. 1981) with a very narrow contact area but a long history of introgression; jack pine and lodgepole pine (Moss 1949; Govindaraju et al. 1989; Wagner et al. 1990) where range overlap is relatively large, and there is evidence of historical divergence and modern introgression; white spruce and Sitka spruce (Lutz spruce) (Little 1953; Wright 1955; Daubenmire 1968; Copes and Beckwith 1977) with an extensive contact area (Kenai Peninsula and Chugach, Alaska) and the species freely cross; white spruce and Engelmann spruce (Garman 1957; LaRoi and Dugle 1968; Kiss 1975; Daubenmire 1974) with an extensive contact area and the species freely cross. Species have developed "Interior spruce" complexes.

\section{Limited Crossing: A Non-Introgressed Species Pair}

A contrasting type of species pair is provided by black spruce, the boreal species, and red spruce, a temperate, non-boreal species. Both species have their own environmental spectrum (nîches) to which they are well-adapted. These spectra, however, are in part both geographic (edaphic and climatic) and temporal (successional) and they do overlap. The tolerances of the species also overlap at these points. Black and red spruce are able to hybridize but they do so only in a very limited way. Unlike white spruce and Engelmann spruce or white spruce and Sitka spruce, which freely hybridize, and whose crossabilities (as assessed by artificial hybridization) are very high, $>50 \%$ (Fowler 1987) the crossability of black and red spruce is quite low, usually not more than 3\% (Gordon 1976), commonly 
$0 \%$, and rarely as high as $5 \%$. Although heterosis (hybrid vigour) is sometimes noted, hybrid seedlings, even when obtained, are often weak (Morgenstern and Fowler 1969). Manley and Ledig (1979) using $\mathrm{CO}_{2}$ exchange measurements, documented physiological limitations in light response, temperature and light accumulation of these hybrids as well as backcrosses and recurrent backcrosses and found that in all environments tested they were inferior to one or other of the parent species. They showed that negative heterosis in hybrids and hybrid derivatives represented a mechanism of reproductive isolation, that of hybrid inferiority. Where competition is reduced, individual hybrids or, more rarely, even hybrid swarms occasionally occur where the two species overlap, but under natural forest ecosystem processes the two species do not genetically merge, as do white and Engelmann spruce, but remain distinct.

\section{An Essentially Non-Crossing Species Pair}

A further contrasting model of a species pair is provided by black and white spruce. They essentially share much of the same range and in many places even the same sites. One may even have been involved in the evolution of the other. Genetic barriers between them are high, and verified examples of natural hybridizing are unknown except for one putative hybrid, the Rosendahl spruce, (Picea glauca $\times$ mariana), discovered in northeastern Minnesota (Little and Pauley 1958). This hybrid has been verified in a number of studies: meosis and pollen release (Winton 1964); terpene composition of leaf oil (von Rudloff and Holst 1968) and crossability (Gordon 1986). Artificial crosses of black and white spruce from many parts of their range have been attempted literally hundreds of times by many workers. Almost all supposed hybrid seedlings have proven to be contaminants (non hybrid). There are only a few known artificial hybrid seedlings surviving (Fowler et al. 1980; Gordon 1980).

\section{Rare Hybrids}

Two other hybrids are of interest. The first of these deals with black and Sitka spruce, the ranges of which touch only slightly in the vicinity of Cook Inlet, Alaska. Many contact stands were examined with no sign of hybridization, but two minuscule and isolated areas ( $<1 \mathrm{ha}$ ) where a few hybrids of varying ages, seedlings to immature trees, were located (Gordon 1985). Although crossability is quite low, artificial hybrids have been made by Fowler et al. (1980), Hoffman and Kleinschmit (1979) and Gordon (1982). The complexity of interspecific relationships is indicated when it is noted that black spruce crosses at a low level but consistently with Sitka, and essentially (with a few rare exceptions) not at all with white spruce, which in turn crosses freely with Sitka spruce.

The second hybrid of interest is thus far the only known natural tri-hybrid, a Lutz spruce (white $\times$ Sitka) $\times$ black spruce, a single tree out of thousands examined, located in southwestern Alaska (Gordon 1986). Artificial tri-hybrid crossing of this combination was successful at very low crossability levels (Gordon et al. 1988).

\section{Artificial Hybrids: Interspecific Breeding}

Artificial hybridization has been extensively carried out with the boreal poplars. Balsam poplar (Populus balsamifera) and black cottonwood (P.trichocarpa) which, as noted, introgress naturally, may be crossed with some ease with others in their Section, Takamahaca, for example $P$. maximowiczii, and also with others, e.g. $P$. deltoides and $P$. nigra in Sec. Aigeiros. Trembling aspen ( $P$. tremuloides) may be crossed with some ease with others in its own Sec. Leuce, e.g. $P$. tremula, and $P$. sieboldii and may also, with greater difficulty be crossed with species in Sec. Aigeiros, e.g. P. deltoides (Zuffa 1975). These crosses are incorporated into many well known poplar improvement and utilization programs. Tables 1 and 2 present information on the crossability of white and black spruce.

\section{Nutrient Status and Implications for Harvesting: A Difference}

A widely accepted view of full-tree clear cut harvesting holds that it mimics natural periodic phenomena such as fire and insect infestations. The single commonality of these perturbations is that the forest is all destroyed or removed at the same time. Beyond this, very little is the same. For those who are familiar with, or work in great forests growing on soils formed from fine-grained volcanic rocks or uplifted calcareous sediments such as those of the Rocky Mountains, one might be forgiven for not instinctively worrying about nutrient loss since available nutrient reserves in such soils are high and harvest-depleted nutrient pools may be rapidly replenished. However, over vast areas in the boreal, soils are acidic and relatively nutrient-poor, being derived from granitic rock of the largest precambrian shield in the world. Even here certain soils such as those of lacustrine origin derived from sedimentary sources elsewhere may be sufficiently nutrient rich and active enough to sustain full-tree clear cut harvesting (Gordon 1983).

However, for the large areas of soils that are derived from sedimentary substrates, for example in the Yukon and Alaska, and in common with the granitic soils, all soil processes are under strong climatic control. The soils, designated 'cryic', are universally cold, and soil weathering processes are very slow (Viereck et al. 1983) so nutrient loss and replacement are important with respect to nutrient removals in harvesting, which is totally dissimilar to the effects associated with fire or insect devastation.

\section{Concepts of Population Genetics and Implications for Management Genetic Diversity}

A second major difference concerns genetic diversity and gene pool preservation and stability. This is a major concern which is little understood and scarcely addressed by many of those engaged in the arguments regarding harvesting. Genetic diversity deals with the genetic differences within a species or population. It consists of the variability of genes calculated from the number and frequencies of alleles and their combinations (Langner and Flather 1994) as measured by isozyme techniques. Fitness for growth and reproduction in the environment and adaptability, for example, to withstand changes, or invade new terrain etc., are dependent on genetic diversity. These are related to a number of attributes, principal for resource management, of which are population size, distribution and density. (Others are levels of gene flow, inbreeding rates, population structure, etc.). It will become increasingly important to genetically survey such attributes in order to insure their limits of maintenance and requirements for restoration in critical cases. 
Table 1. Cross compatibility of white spruce Picea glauca and other Picea species

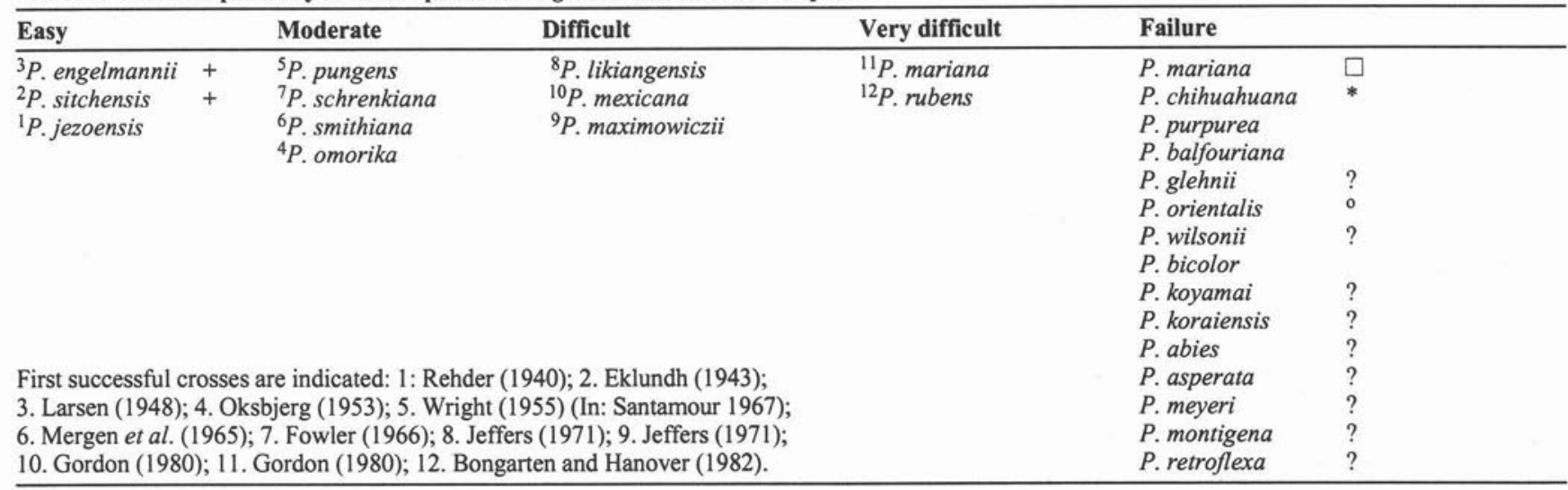

Table 2. Cross compatability of black spruce Picea mariana and other Picea species.

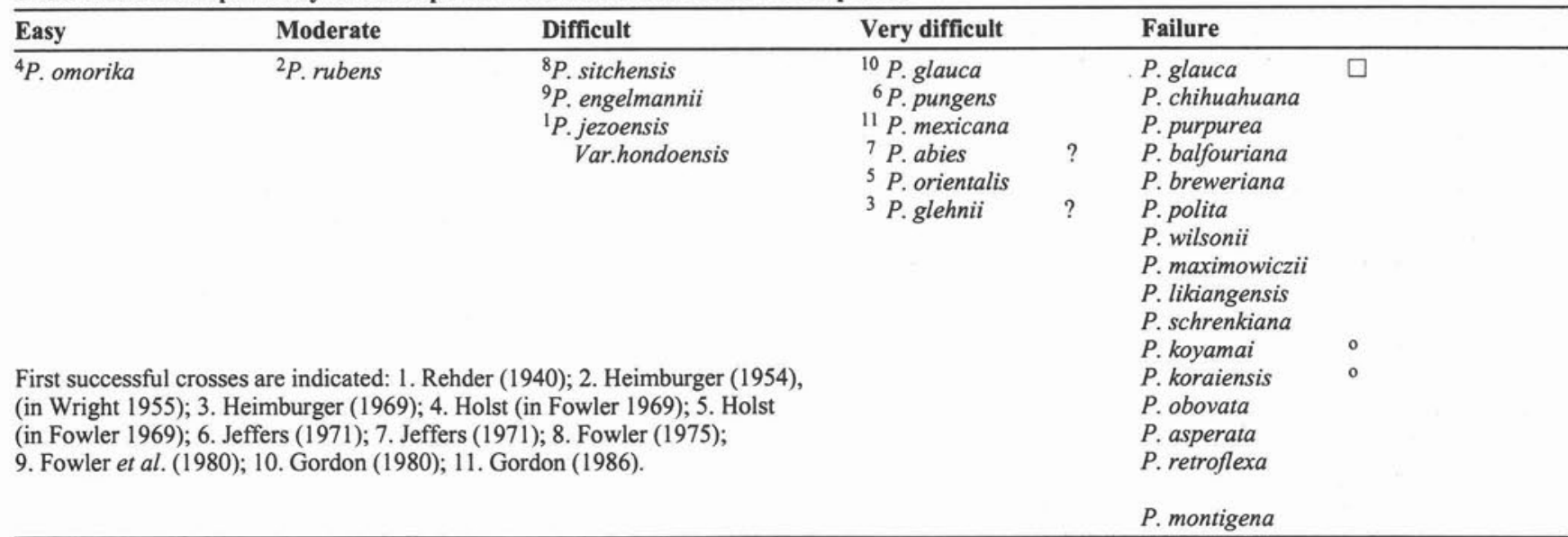

+Also introgression

*Consistent failure

$\square$ Almost consistent failure

? Hybrid reported by one worker, but attempts by all other workers have consistently failed (hybrid still unverified)

o Hybrid reported by one worker, few seedlings obtained, never verified. Contamination known to be present.

Simply put, if populations become too small, or too far apart, or individuals of one species within a mixture are too isolated from one another, pollination is incomplete. Inbreeding with related near neighbours, or, worst scenario, selfing (an outcrossing, wind pollinating species mating with itself) may ensue. This results in inbreeding depression in which low numbers of deleterious genes from each parent (the ever present products of random mutation) are more likely to become paired in chromosome pairs in the progeny. This condition is said to be homozygous and results in some form of dysfunction, sometimes lethal in the tree. This can commence with embryo inviability, or lowered germination (Cheliak et al. 1985), reduced productivity (reduced height and diameter growth) and if the tree lives that long, subsequent failure to reproduce properly. This process can result in remnant stands becoming still smaller, less fit to contend with competition from other species with which they previously competed satisfactorily, less adapted and hence less able to regenerate into new ground even site-prepared for them. Buchert et al. (1995) compared pre and post harvest residual old growth white pine stands in central Ontario and found genetic diversity was reduced by $25 \%$. In addition, $80 \%$ of the rare alleles were lost in the harvesting. The ensuring progeny, if any, being derived from residual post harvest populations will be starting from a substantially lowered genetic base and many never survive. It is critical that the residual number of stems $\mathrm{ha}^{-1}$ left following harvesting be sufficient to hold the genetic diversity of the original stand.

Outcrossing, on the other hand, results in matings in which any deleterious genes are much more likely to be paired with normal genes. In such cases deleterious effects are most commonly masked or may be eliminated. Harvesting systems which leave remnant groves both too sparse and too far apart cause losses in genetic diversity within the groves and can arrest gene flow between them. A process known as "genetic drift" is also initiated which gradually reduces genetic diversity. The remnants gradually disappear. This is the opposite effect of a species experiencing expansion because, perhaps, of major environmental change, for example during the closing of the Pleistocene, or the gradual colonization of cutovers or burns by pioneer species. In this case outliers from the main stand are established by seed flight on suitable sites and the matrix species advances towards them by successional processes until gene flow is established.

Because new habitats are initially more severe, it is thought that populations of trees at the advancing front will be less variable because of high natural selection pressure and expected 
selfing phenomena in low density populations. Alden and Loopstra (1987) however, have shown that white spruce at the upper tree limit in Central Alaska were as genetically diverse as earlier established populations at low elevation. Tigerstedt (1993) notes a similar condition in high latitude tree line populations of Norway spruce in Finland.

\section{Local Species Extinction and Hybrid Enhancement}

Another phenomenon noted independently by Gordon (1976), and Manley and Ledig (1979) deals with the relationship between red and black spruce. It has been noted that these species do hybridize at low levels but that in natural circumstances, and despite long time contact, they maintain their species integrity. It had been supposed that hybrids survived best in so-called "hybrid habitats" yet these were difficult to find. The hybrids actually survived best in habitats where competition from the parent species, particularly red spruce, as well as other species had been removed or reduced by clearcutting. Stand data from Ontario indicated that on average clearcutting reduced red spruce from $788 \mathrm{stems} \mathrm{ha}^{-1}$ (exclusive of other species) to less than 10 stems ha- $^{-1}$. Red spruce is not a fire strategy species and does not regenerate in clearcuts. Except for some specialized habitats with very humid misty local climates, it essentially becomes locally extinct following clearcuts.

In the Canadian Maritimes clear cut loggers invariably leave a few red spruce, missed accidentally or because of small size or poor form. As these scattered remnants of red spruce mature, they are flooded with pollen from the pockets of black spruce remaining in bogs where they were never logged because of small sizes and harvesting difficulties on poorly drained sites. Even though crossability is low, hybrids are produced and survive because there is little or no red spruce pollen any longer available, and no longer any competition on what is now the so-called "hybrid habitat". Gradually with time, even though they are less adapted than the parents on parental sites (red spruce for shade tolerance and ability to compete with hardwoods on uplands, black spruce for water tolerance and ability to grow on wet sites) more hybrids appear. Red spruce disappears and is generally replaced by hardwoods with which it once competed successfully, not as a result of natural processes, but rather because of a totally inappropriate harvesting system for this species.

\section{Life Strategies and Silvicultural Systems \\ Seed Tree, Selection and Shelterwood Systems}

The seed tree method of regeneration projected in many early silvicultural textbooks is essentially inappropriate for maintenance of local gene pools of many forest species and would initiate genetic erosion. It is anticipated that there would be insufficient seed trees left to maintain genetic diversity. The selection system, ideal only for tolerant species but perhaps possible to modify for the north, and the shelterwood system are good for gene pool conservation of many species, providing there are sufficient trees left per hectare (Zasada and Grigal 1978). The genetic diversity of the regeneration should be at least equal to that of the preharvest overstory.

\section{Clear Cuts}

Most boreal species have adapted to even-aged growth strategies, as have many intolerant temperate species, e.g. oaks,
Douglas fir etc. Some very shade-intolerant species are able to maximize their development while exploiting poorer (dry or wet) soils where they are free of interspecific competition. Their more nutrient-demanding competitors are unable to follow them on such sites. Examples are jack and lodgepole pine which exploit the very well-drained or drier sites, and black spruce which tolerates the moist to wet, acidic sites. These species on such sites have simple monoculture stand structures. Both black spruce and jack pine have evolved specialized but different reproduction strategies to release unburned seed following a fire. Such stands may be clearcut providing care is taken to scatter the slash, mimicking a fire by getting the cones near the ground where they will open in summer heat. With black spruce, there is the added constraint of winter-harvesting in order to prevent disruption of moist or wetland surfaces. The regeneration from cones in the slash should be sufficient to capture the existing gene pool, although studies may be required to confirm this. If natural regeneration from cones in the slash or from layering fails, planting will be essential.

\section{Modified Clear Cuts}

Black spruce has a bimodal distribution with one peak on wet sites and a second peak on intermittently dry sites. Along with jack pine and white birch it may occupy very shallow soils over bedrock, dry sites where competition is reduced. On these dry sites or other upland soils some form of modified harvesting (Jeglum and Kennington 1993) will be required to conserve such gene pools. Consideration should be given to the size of clearcut. Care must be taken to conserve portions of uncut standing timber until the regeneration is captured on cut portions. Size of opening is important and should be related to known or measured seeding distance.

\section{White Spruce and Associates: Two Forests on the Same Site}

Other boreal species, white spruce, balsam fir, white birch and aspen are relatively even-aged species, but they are different than black spruce and jack pine, and in any of their common mixtures respond differently to many environmental stimuli. Their more nutrient-demanding requirements cause these species to occupy sites which invite competition not only between them but also from ground vegetation and many shrub species. Trembling aspen, balsam poplar and white birch are shade intolerant, relatively short-lived, even-aged species, while white spruce is intermediate in tolerance and has the greatest longevity. Balsam fir is very tolerant but is not long-lived. Because of their differences in tolerance, longevity, regeneration life strategies and competitive site requirements, these species, while growing in pure stands in some areas, often develop complex mixtures in time and space which on analysis actually constitute two, or occasionally more, forests, growing on the same site, at the same time, but at different stages in their development.

White spruce from Ontario and Quebec to Alaska has variable but common strategies for different mixtures. Except where it is re-invading following fire, white spruce must, and often does set a regeneration cohort before the old trees go down. This cohort is often suppressed for years as aspen rise and mature. It is in such circumstances that the practices of clearcutting or cutting out the spruce and leaving the aspen have been based on assumptions that vastly oversimplify how these forests function and repeat themselves. Without rehabilitation, the spruce, 
to say nothing of well-adapted gene complexes, is gone essentially forever. In the second scenario, cutting out one forest, the spruce, and leaving the other, the aspen, (two forests on the same site at different stages) may look acceptable, but in reality has probably halved the biodiversity, considering all the related organisms from lichens to blackburnian warblers and moose.

\section{Spruce-Fir Stand Dynamics and the Budworm}

The stand dynamics of balsam fir and white spruce in eastern and central North America and red spruce in the cool temperate forests of the east is a complex system which in the presence of spruce budworm recurrently enables white and red spruce to escape the obliterating competition of balsam fir sufficiently to establish the next rotation of spruce (Gordon 1985). Where balsam fir is absent, for example in the Yukon and Alaska, other closely-related models apply. Balsam fir has evolved with the budworm and is unquestionably sustainable. Within its range it is not in danger as a species. There is scarcely a harvesting system, including clear cutting, that will not work with this species.

\section{Fire and Insects vs. Harvesting: A Second Difference}

To infer that either of the two foregoing harvesting methods mimic those of nature, particularly fire or insects, represents at best well-intentioned naïveté but in reality is a misleading interpretation of known eco-genetical and biogeochemical processes. Natural perturbations do not erode the gene pools. Unburned forest walls subtend fire margins and local populations are renewed by external migration from adjacent seed sources. Throughout the burned areas small patches of surviving trees or regeneration may also survive. In addition, the mechanisms of reproduction in most boreal species have evolved with fire as a principal component of selection. In white spruce, as with many other species, the dry weather which enables a fire to originate and burn is also the environmental switch initiating primordia development into strobili, giving rise to pollen and seed the following year. Any trees which survive the burn even for a year or two will be showering the burned ground with seed the following year. While not all stands burn in the boreal forest (many do break up at overmaturity and renew in situ) fire is nevertheless a major factor in succession. It is a system that has worked through-out great periods of time in the absence of harvesting, with a small number of species, some more site- specific than others, following one another on the same or adjacent sites with no ultimate loss in any of their gene pools. The "stable" pattern of the boreal is maintained, endlessly changing, endlessly the same.

In clearcut harvesting, whether all species or single species are removed, gene pools are seriously eroded or even lost. If same-source planting is impossible, the same regional source should be used. If it is not possible, or not economically expedient to plant, then removing white spruce from boreal mixedwood before regeneration is secured results in virtual elimination of this species. Clear cutting, site preparation and planting offers a reasonable chance of genic capture but the loss of adaptability is still a strong possibility. Gömöry (1992) compared the genetic structure of natural virgin stands and plantations of Norway spruce in Slovakia and found that the mature stands did not differ negatively from that of natural regen- eration, genetic variation being actually higher in the latter, but in plantations it was noticeably decreased. Similarly, Rajora and Dancik (1994) found a marked reduction (12\%) in genetic diversity of white spruce plantations as compared to that of natural regeneration and uncut stands in Saskatchewan. Tree improvement programs attempt to capture this, but once harvesting commences the pace is so rapid there seems little chance TI procedures can catch up. There is still a widespread economic tendency to designate northern forests as exploitable (old growth liquidation) while accepting increasingly high levels of unregenerated cutover backlog and designating it "naturally regenerated". To what? one might ask. Why, to scattered poplar, birch, willow, alder or ericaceous brush. Fortunately, after many years more thoughtful silvicultural procedures are now being developed (Scarratt 1992; Navratil et al. 1994).

\section{Legacy and the Future}

To assume that our harvesting systems have thus far done no damage to our forests both in terms of reduced biodiversity and loss of genetic diversity and that we are not anticipating further mass losses in future harvesting operations is naïve in the extreme. Namkoong, (1984) notes that we have created conditions that threaten extinction of alleles and populations for many species, including critically important crop species. One only has to consider the historical removal of white pine from enormous tracts of forests in eastern North America. To this can be added the commercial extinction of yellow birch in Ontario, Quebec and probably the Maritime Provinces and New England. Perhaps with the exception of Pennsylvania, eastern hemlock has been drastically reduced in all of the foregoing areas. In many places stands and groves are not being renewed, particularly following clearcutting (Hix and Barnes 1984; Anderson 1992).

The range occupancy of red spruce has been drastically reduced. Buttrick (1916) pointed out that red spruce was the leading pulpwood species in the U.S. (which was at that time leading the world in pulpwood consumption) accounting for $70 \%$ of all pulp. Hoyle (1952) noted that for red spruce saw timber in New York alone in 1912, 166 million bd.ft. were utilized, 149 million in 1919, 58 million in 1926 and 12.5 million in 1946. Diameter limit cutting during that period would also have genetically run the stands down, preserving genes conditioning slow growth which would render these in higher frequencies in ensuing stands. The current site occupancy of this species is estimated at about one fifth of its former extent. Yet it is currently still being reduced essentially through clearcutting and stand conversion in large areas in Maine and New Brunswick. In many places in south central and eastern Ontario (Gordon 1992), the St. Lawrence Valley and the Eastern Townships of Quebec, the Maritime Provinces, as well as in Northern Vermont and New Hampshire where biomass harvesting for power generation results in clearcutting mid and upper slope landscapes, continued cutting predicates that many small stands and isolates of red spruce, both pure and in conifer hardwood stands, which are themselves already only remnants of historical cutting, will collapse and disappear. Local extinctions are occurring throughout large areas of the northeast right now. As with any form of forest fragmentation, the matrix populations themselves then commence to become vulnerable as their edges start to fray.

In Ontario and parts of some other provinces right to Cape Breton Island, vast areas of white spruce in the boreal forest 
originally seemed inexhaustible. White spruce has been removed from mixed conifer hardwood stands, and although much of the easy-to-site-prepare land has been planted, it is now conceded that the inventory of this species in many areas has shrunk to the level formerly considered as that designated to minor species. This could happen quickly in the Yukon and Alaska once it commences.

\section{Acknowledgments}

I would like to thank the late H. Douglas Long, my professor of dendrology, ecology and silviculture at the University of New Brunswick, the late G. Angus Hills, physiographer and site ecologist, and the late Carl C. Heimburger, ecologist and geneticist, all of whom were my mentors and friends, and pointed the direction; and my colleagues John Zasada USFS, ecologist/silviculturalist, John Alden, USFS, geneticist, and George Buchert OFRI, geneticist, with two of whom I have spent much time travelling in the northern forests and with all of whom I spend much time in fruitful discussion. To John Zasada, George Buchert and Nancy Tibbles, a special thanks for reviewing the manuscript.

\section{References}

Alden, J. and C. Loopstra. 1987. Genetic diversity and population structure of Picea glauca on an altitudinal gradient in interior Alaska. Can. J. For. Res. 17: 1519-1526.

Anderson, H.W. 1992. Hemlock: Its ecology and management. Pp. 62-98 In: B. Naylor and L. Thompson (Eds.) Regenerating conifer cover in deer yards. Cent. Ont. For. Tech. Dev. Unit. Workshop. North Bay, Ont. Dec. 1990. Tech. Rep. No. 28. (Also available in: The tolerant conifers, Ont. For. Res. Inst., For. Res. Info. paper No. 113 1994). Axelrod, D.I. 1944. Pliocene floras of California and Oregon. R.W. Chaney (Ed.). Carnegie Inst. Wash. Pub. 553. Washington, DC. Barnes, B. V., B. P. Dancik and T. L. Sharik. 1974. Natural hybridization of yellow birch and paper birch. For. Sci. 20 (3): 215-221.

Beaudoin, R., A. Stipanicic et G. Vallée. 1984. Amélioration des arbres forestiers, au Service de la Recherche du Ministère de L'Energie et des Ressources du Quebec. Proc. 19th C.T.I.A. Mtg., Toronto, ON. 22-26 Aug. 1983. p. 68-75.

Beaulieu, J., A. Corriveau and G. Daoust. 1989. Phenotypic stability and delineation of black spruce breeding zones in Quebec. Can. For. Serv. Laurent. For. Res. Cent. Inf. Rep. LAU-X-85 E.

Becker, H. F. 1973. The York Ranch flora of the Upper Ruby River Basin, southwestern Montana. Palaeontographica B, 143, no 1-4: 18-93.

Bihun, Y.M. and K.K Carter. 1983. Range-wide study of black spruce in northern Maine. Proc. of the 28th Northeastern For. Tree Impr. Conf., Univ. New Hampshire, Durham, 7-9 July 1982. USDA For. Serv. Durham. NH. p. 1-11.

Bongarten, B.C. and J.W. Hanover. 1982. Hybridization among white, red, blue and white $\times$ blue spruces. For. Sci. 28: 129-134.

Boyle, T.J.B. 1985. Range-wide provenance tests of black spruce in Ontario. Can. For. Serv. Petawawa Natl. For. Inst. Inf. Rep. P-1-X$57.36 \mathrm{p}$.

Brubaker, L. 1983. (in Heimburger 1984).

Brubaker, L. 1994. Boreal forest responses to climate warming: Lessons from the past. In: Managing Forests to Meet People's Needs. Society of American Foresters/Canadian Institute of Forestry, Anchorage, AK. 18-22 Sept.

Buchert, G. P., O. P. Rajora, J. V. Hood and B. P. Dancik. 1995. Genetic implications of silvicultural management of eastern white pine. I. Effects of harvesting on genetic diversity in old growth stands. (in prep).

Bush, R. M. and P. E. Smouse. 1992. Evidence for the adaptive sig- nificance of allozymes in forest trees. New Forests 6: 179-196. Buttrick, P.L. 1916. Commercial uses of red spruce. Amer. Forestry 22 (276): 707-711.

Cheliak, W.M. and J.A. Pitel. 1984. Biochemical genetics 19811983. Proc. 19th C.T.I.A. Mtg., Toronto, ON. 22-26 Aug. 1983. p. 121-125.

Cheliak, W.M., B.P. Dancik, R. Morgan, F.C.H. Yeh and C. Strobek. 1985. Temporal Variation of the mating system in a natural population of jack pine. Genetics 109: 569-584.

Cheliak, W.M., G. Murray and J.A. Pitel. 1988. Genetic effects of phenotypic selection in white spruce. For. Ecol. Manage. 24: 139-149. Copes, D.L. and R.C. Beckwith. 1977. Isoenzyme identification of Picea glauca, P. sitchensis, and P. lutzii populations. Bot. Gaz. 138 (4): 512-521.

Corriveau, A.G. 1982. Variabilité spatiale et temporelle de la croissance juvénile des provenances d'épinette noire au Québec. Proc. 18th C.T.I.A. Mtg., Duncan, BC. 18-21 Aug. 1981 p. 181-187.

Corriveau. A.G. and G. Vallée 1981. Forest genetics and tree improvement are on the way in Quebec. For. Chron. 57: 165-169. Critchfield, W. B., and E. L. Little Jr. 1966. Geographic distribution of the pines of the world. U.S.D.A. For. Serv. Misc. Pub. 991. $97 \mathrm{p}$.

Dallimore, W. and A. B. Jackson 1948. A handbook of Coniferae including Ginkgoaceae. Edward Arnold \& Co., London. 682 p.

Dancik, B. P. and F. C. Yeh 1983. Allozyme variability and evolution of lodgepole pine (Pinus contorta var. latifolia) and jack pine (P. banksiana) in Alberta Can. J. For. Res. 25: 57-64.

Danzmann, R. G. and G. P. Buchert. 1982. Isozyme variability in Central Ontario jack pine. Pp. 232-248 In: R.T. Eckhert (Ed.) Proc. 28th NEFTIC, Durham, NH.

Daubenmire, R. 1968. Some geographic variations in Picea sitchensis and their ecologic interpretation. Can. J. Bot. 46: 787-798.

Daubenmire, R. 1974. Taxonomic and ecological relationships between Picea glauca and Picea engelmannii. Can. J. Bot. 52 (7): 1545-1568.

Delcourt, P. A. and H. R. Delcourt. 1987. Long-term forest dynamics of the temperate zone. Springer-Verlag, New York, Berlin, Heidelberg. 439 p.

Dietrichson, J. 1969. Genetic variation of cold damage, growth rhythm and height growth in 4-year old black spruce (Picea mariana (Mill.) B.S.P.). Medd. Nor. Skogforsoksves. Nr. 97. Bd. 27. H.2. p. 110-129. Eklundh, C. 1943. Art Korsningar inom sl. Abies, Pseudotsuga, Picea, Larix, Pinus och Chamaecyparis tillhörande fam. Pinaceae Sven. Papperstidn, 46: 55-61, 101-105, 130-133.

Farmer, R.E., Jr. and R.W. Reinholt. 1986. Genetic variation in dormancy relations in balsam poplar along a latitudinal transect in northwestern Ontario. Silvae Genetica 35 (1): 38-42.

Florin, R. 1963. The distribution of Conifer and Taxad genera in time and space. Acta Horti Bergiani 20: 121-311.

Fowler, D.P. 1966. A new spruce hybrid-Picea schrenkiana $\times P$. glauca. U.S.D.A. For. Serv. Res. Pop. NC-6: $44-47$.

Fowler, D.P. 1976. Hybridization in Picea and Larix. Proc. 15th C.T.I.A. Mtg., Petawawa For. Exp. Stat. ON., 18-22 Aug. 1975. p. 34-37.

Fowler, D.P. 1987. The hybrid white $\times$ Sitka spruce: species crossability. Can. J. For. Res. 17: 413-417.

Fowler, D.P. and R.E. Mullin. 1977. Upland-lowland ecotypes not well developed in black spruce in northern Ontario. Can. J. For. Res. 7: $35-40$.

Fowler, D.P. and Y.S. Park. 1982. Range-wide black spruce provenance trials in the Maritimes. Can. For. Serv. Maritimes For. Res. Cent. Inf. Rep. M-X-137.

Fowler, D.P., J.M. Bonga, J.F. Coles, Y.S. Park and R.F. Smith. 1980. Tree breeding at the Maritimes Forest Research Centre 1977 and 1978. Proc. 17th C.T.I.A. Mtg., Gander, Newfoundland, 27-30 Aug. 1979. p. 81-87.

Fowler, D.P., J.M. Bonga, Y.S. Park, J.D. Simpson and R.F. Smith. 1986. Tree breeding at the Maritimes Forest Research Centre 1983 
and 1984. Proc. 20th C.T.I.A. Mtg., Quebec City, PQ. 19-22 Aug. 1985. p. 58-63.

Garman, E.H. 1957. The occurrence of spruce in the interior of British Columbia. Dept. Lands For. BC For. Serv. Tech. Pub. T.49. 31 p. Gömöry, D. 1992. Effect of stand origin on the diversity of Norway spruce (Picea abies Karst.) populations. For. Ecol. Manage. 54: 215-223. Gordon, A.G. 1976. The taxonomy and genetics of Picea rubens and its relationship to Picea mariana. Can. J. Bot 54(9): 781-783.

Gordon, A.G. 1980. Spruce genetics, Sault Ste. Marie, 1977 and 1978. Proc. 17th C.T.I.A. Mtg., Gander, Newfoundland. 27-30 Aug. 1979. p. $117-121$

Gordon, A.G. 1982. Genetics and genecology of spruce, Sault Ste. Marie, Ont. 1979 and 1980. Proc. 18th Can. Tree Impr. Assoc. Mtg., Duncan, BC. 18-21 Aug. 1981. p. 112-115.

Gordon, A.G. 1983. Nutrient cycling dynamics in differing spruce and mixedwood ecosystems in Ontario and the effects of nutrient removals through harvesting. In: R.W. Wein, R.R. Riewe and I.R. Methven. (Eds.) Resources and dynamics of the Boreal Zone. Assoc. Can. Univ. for Northern Studies, Ottawa, On. p. 97-118.

Gordon, A.G. 1985. Budworm! What about the forest? Pp. 3-29 In: D. Schmitt (Ed.) Spruce-fir management and spruce budworm. CANUSA Spruce Budworm Program, U.S.D.A. For. Serv. Gen. Tech. Rept. N.E. 99.

Gordon, A.G. 1986. Breeding, genetics and genecological studies in spruce for tree improvement in 1983 and 1984, Sault Ste. Marie, Ont. Proc. 20th C.T.I.A. Mtg., Quebec City, PQ. 19-22 Aug. 1985. p. $112-116$.

Gordon, A.G. 1992. The red spruce option: red spruce and the hemlock connection. Pp. 99-114 In: B. Naylor and L. Thompson (Eds.) Regenerating conifer cover in deer yards. Cent. Ont. For. Tech. Dev. Unit. Workshop North Bay, Ont. Dec. 1990. Tech. Rep. No. 28. (Also available in: The tolerant conifers, Ont. For. Res. Inst., For. Res. Info. Paper No. 113 1994).

Gordon, A.G., G.P. Buchert and R.H. Ho. 1988. Forest Genetics Research at the Ontario Tree Improvement and Forest Biomass Institute. Proc. 21 st C.T.I.A. Mtg., Truro, NS. 17-21 Aug. 1987. p. 58-63.

Govindaraju, D.R. and B.P. Dancik. 1987. Allozyme heterozygosity and homeostasis in germinating seeds of jack pine. Heredity 59: 279-283. Govindaraju, D.R., B.P. Dancik, and D.B. Wagner. 1989. Novel chloraplast DNA polymorphism in a sympatric region of two pines. J. evol. Biol. 2: 49-59.

Graham, A. 1965. The Sucker Creek and Trout Creek Miocene floras of southeastern Oregon. Kent State University Bulletin, Res. Ser. IX, Kent State Univ. Press, Kent, Ohio. 143 p.

Grant, W.F. and B.K. Thompson. 1975. Observations on Canadian birches, Betula cordifolia, B. neoalaskana, B. populifolia, B. papyrifera, and B. $\times$ caerulea. Can. J. Bot. 53 (15): 1478-1490.

Heimburger, C.C. 1954 (in Wright 1955).

Heimburger, C.C. 1969. Summary report on forest tree breeding 1966 and 1967. Proc. 11th Comm. For. Tree Breed. in Canada Mtg., Macdonald Coll., PQ. 8-10 Aug. 1968. p. 55-61.

Heimburger, C.C. 1984. The evolution of black spruce. Proc. 19th Can. Tree Impr. Assoc. Mtg. Toronto, ON. 22-26 Aug. 1983. p. 163-166, (and notes).

Hills, G.A. 1960. Regional site research. For. Chron. 36 (4): 401-423. Hills, L.V. and R.T. Ogilvie. 1970. Picea banksii n. sp. Beaufort Formation (Tertiary), northwestern Banks Island, Arctic Canada. Can. J. Bot. 48: 457-464.

Hix, D.M. and B.V. Barnes. 1984. Effects of clear-cutting on the vegetation and soil of an eastern hemlock dominated ecosystem, western Upper Michigan. Can. J. For. Res. 14: 914-923.

Hoffman, D. and J. Kleinschmit. 1979. A utilization program for spruce provenances and species hybrids. Proc. I.U.F.R.O. Norway spruce Mtg. S2.03.11 and S2.02.11 Bucharest. Pub. Lower Saxony For. Res. Inst. Escherode, West Germany. p. 216-236.

Holst, M.J. 1960. Genetics as a factor in quality control. Pulp and
Paper Mgmt. Can. 61: 150-144.

Holst, M.J. 1969. Pp. 33-36 In: D.P. Fowler. Tree breeding in the Maritimes Region 1966-67. Proc. 11 th C.F.T.B.C. Mtg., Macdonald Coll., PQ. 8-10 Aug. 1968.

Hopkins, D.M., J.V. Mathews, J.A. Wolfe and M.L. Silberman. 1971. A. Pliocene flora and insect fauna from the Bering Strait Region. Palaeogeography, Palaeoclimatology, Palaeoecology 9: 211-231. Elsevier Pub. Co., Amsterdam.

Hoyle, RJ. 1952. Eastern spruce lumber and its uses. New York Forester. N.Y. Sec. Soc. Amer. For. Spruce No. XI (2) May.

Hunt, R.S. and E. von Rudloff. 1974. Chemosystematic studies in the genus Abies. I leaf and twig oil analysis of alpine and balsam firs. Can. J. Bot. 52 (3): 477-487.

Illingworth, K. 1975. Lodgepole pine genetics, British Columbia, 1971-73. Proc. 14th C.T.I.A. Mtg., Fredericton, NB. 28-30 Aug. 1973. p. 169-174.

Isabel, N., L. Tremblay, M. Michaud, F.M. Tremblay and J. Bousquet. 1993. RAPDs as an aid to evaluate the genetic integrity of somatic embryogenesis-derived populations of Picea mariana (Mill.) B.S.P. Theor. Appl. Genet. 86: 81-87.

Jeffers, R.M. 1971. Research at the Institute of Forest Genetics. U.S.D.A. For. Serv. Res. Pap. NC-67,

$31 \mathrm{p}$.

Jeglum, J.K. and D.J. Kennington. 1993. Strip clearcutting in black spruce: a guide for the practicing forester. Forestry Canada, Ont. Region. $102 \mathrm{p}$.

Joyce, D.G. 1988. Adaptive variation in cold hardiness of eastern larch, Larix laricina, in northern Ontario. Can. J. For. Res. 18: 85-89.

Khalil, M.A.K. 1981. Ten-year results of regional black spruce provenance study in Newfoundland. Can. For. Serv. Inf. Rep. N-X-200: $43 \mathrm{p}$.

Khalil, M.A.K. 1984. All-range black spruce provenance study in Newfoundland: performance and genotypic stability of provenances. Silvae Genetica 33: 63-71.

Kiss, G. 1975. Improvement of white and Engelmann spruce complexes of British Columbia Progress Report. Proc. 14th C.T.I.A. Mtg., Fredericton, NB. 28-30 Aug. 1973. p. 175-176.

Klein, J.I. 1984. Genetic improvement of jack pine for the Prairie Provinces 1981-1983. Proc. 19th C.T.I.A. Mtg., Toronto, ON. 22-26 Aug. 1983. p. 150-153.

Knowles, P. 1985. Comparison of isozyme variation among natural stands and plantations: Jack pine and black spruce. Can. J. For. Res. 15: 902-908.

Knowles, P., R.R. Farmer and W.H. Parker. 1986. Forest genetics research activities at Lakehead University 1983-1985. Proc. 20th C.T.I.A. Mtg., Quebec City, PQ. 19-22 Aug. 1985. p. 154-155. Knowlton, F.H. 1898. The fossil plants of the Payette formation. U.S. Geol. Surv. 18th Ann. Rept., pt 3: 721-744.

Langner, L.L. and C.H. Flather. 1994. Biological diversity: Status and trends in the United States. U.S.D.A. For. Serv. Gen. Tech. Rept. RM-244. 25 p.

LaRoi, G. and J.R. Dugle. 1968. A systematic and genecological study of Picea glauca and Picea engelmannii using paper chromatograms of needle extracts. Can. J. Bot. 46: 649-687.

Larsen, C.S. 1948. Arboretet i Horsholm og forstbotanisk have i Charlottenlund 1948. Föreningens för dendrologi och parkvård årsbok Lunstgården 1947-48: 1-76.

Little, Elbert. E. Jr. 1953. A natural hybrid spruce in Alaska. J. For. 51: 745-747.

Little, E.L. Jr. and S.S. Pauly. 1958. A natural hybrid between black and white spruce in Minnesota. Amer. Mid. Nat. 60: 202-211.

Löve, D. 1959. The postglacial development of the flora of Manitoba: A discussion. Can. J. Bot. 37: 547-585.

MacGinitie, H.D. 1953. Fossil plants of the Florissant Beds, Colorado. Carnegie Inst. Wash. Pub. 599. Washington, DC.

Maini, J.S. and J.H. Cayford. 1968. (Eds.) Growth and utilization of poplars in Canada. Can. Dept. For. and Rural Development. For. 
Br. Pub. 1205. Ottawa, ON. 257 p.

Manley, S.A.M. and F.T. Ledig. 1979. Photosynthesis of black and red spruce and their hybrid derivatives: ecological isolation and hybrid inferiority. Can. J. Bot. 57: 305-314.

Mergen, F., J. Burley and G.M. Furnival. 1965. Embryo and seedling development in Picea glauca (Moench) Voss after self-, cross-, and wind-pollination. Silvae Genetica 14 (6): 188-194.

Merrill, R.E., C.A. Mohn and W. Cromwell. 1984. Survival and height growth of a rangewide black spruce provenance test on two sites in Minnesota. Proc. of the 3rd North Cent. Tree Impr. Assoc. Mtg., Ohio Res. and Dev. Center, Wooster, OH. 17-19 Aug. 1983. Dep. For., Univ. Wisconsin, Madison. p. 34-43.

Morgenstern, E.K. 1969. Genetic variation in seedlings of Picea mariana (Mill.) B.S.P. Silvae Genetica 18: 151-167.

Morgenstern, E.K. 1978. Range-wide genetic variation of black spruce. Can. J. For. Res. 8: 463-473.

Morgenstern, E.K. and D.P. Fowler. 1969. Genetics and breeding of black spruce and red spruce. For. Chron. 45 (6): 1-5.

Morgenstern, E.K. and T.J. Mullin 1990. Growth and survival of black spruce in the range-wide provenance study. Can. J. For. Res. 20: 130-143.

Morris, D. and W.H. Parker. 1992. Variable-quality form in mature jack pine stands: quantification and relationship with environmental factors. Can. J. For. Res. 22: 279-289.

Moss, E.H. 1949. Natural pine hybrids in Alberta. Can. J. Res. C. 27: 218-229.

Murray, G. and W. Cheliak. 1986. Genetics of white spruce, larches and hardwoods, Petawawa 1983-1985. Proc. 20th C.T.I.A. Mtg., Quebec City, PQ. 19-22 Aug. 1985. p. 136-138.

Namkoong, G. 1984. A control concept of gene conservation. Silvae Genetica 33: 4-5, 160-163.

Navratil, S., L.G. Brace, E.A. Sauder and S. Lux. 1994. Silvicultural and harvesting options to favour immature white spruce and aspen regeneration in boreal mixedwoods. Can. For. Serv. Northern Forestry Centre. Info. Rept. Nor-X-337. 78 p.

Nienstaedt, H. 1969. White spruce seed source variation and adaptation to 14 planting sites in northeastern United States and Canada. Proc. 11 th Comm. For. Tree Breed. in Canada Mtg. Macdonald Coll. PQ. 8-10 Aug. 1968, p. 183-184.

Nienstaedt, H. 1984. Breeding implications of juvenile selection in a range-wide black spruce provenance test. Can. J. For. Res. 14: 933-939. Oksbjerg, E. 1953. On Picea omorika Skovfor. Tidsskr. 2: 179-192. O'Reilly, G.J., W.H. Parker and W.M. Cheliak. 1985. Isozyme differentiation of upland and lowland Picea mariana stands in northern Ontario. Silvae Genetica 34 (6): 214-221.

Park, Y.S. and D.P. Fowler, 1988. Geographic variation of black spruce in the maritimes. Can. J. For. Res. 18: 106-114.

Parker, W.H., J. Maze and G.E. Bradfield. 1981. Implications of morphological and anatomical variation in Abies balsamea and $A$. lasiocarpa (Pinaceae) from western Canada. Amer. J. Bot. 68 (6): 843-854.

Rajora, O.P., B.P. Dancik and M. Aleksiuk, 1991. Associations of genes encoding allozymes of peroxidase and superoxide dismutase in poplar and spruce species. Theor. Appl. Genet. 81: 729-734. Rajora, O.P., L. Zuffa and B.P. Dancik. 1991. Allozyme and leaf morphological variation of eastern cottonwood at the northern limits of its range in Ontario. Forest Science 37 (2): 688-702.

Rajora, O.P. and B.P. Dancik. 1994. Genetic diversity in white spruce forest in Saskatchewan. Interim Rep. for Prince Albert model forest. Dept. Renew. Res., Univ. Alta., Edmonton, AB. 10 p.

Rehder, A. 1940. Manual of cultivated trees and shrubs. MacMillan Co., NY. 996 p

Ritchie, J.C. 1987. Postglacial vegetation of Canada. Cambridge University Press, Cambridge. 178 p.

Ritchie, J.C. and G.M. MacDonald. 1986. The patterns of post-glacial spread of white spruce. J. Biogeography 13: 527-540.

Santamour, F.S. 1967. Growth and characteristics of some hybrid spruces. Morris Arboretum Bull. 18: 1820.

Scarratt, J.B. 1992. (Ed.) A soft touch, opportunities for careful harvesting and understory protection, Workshop. Forestry Canada, Great Lakes Forestry Centre, Sault Ste. Marie, ON. 59 p.

Skeates, D.A. and D.E. Irving. 1988. Nursery indications of white spruce provenance variability in northwestern Ontario. Ont. Min. Nat. Res., For. Res. Rept. No. 122.13 p.

Tiech, A.H. and M.J. Holst. 1974. White spruce limestone ecotypes. For. Chron. 50: 110-111.

Tiech, A.H., D.A. Skeates and E.K. Morgenstern. 1975. Performance of white spruce provenances in Ontario. Special Joint Rept. \#1. Can. For. Serv., Petawawa For. Exp. Stat. and Ont. Min. Nat. Res., Res. Br. 31 p.

Tigerstedt, P.M.A. 1993. Genetic diversity of tree populations at their Arctic limits. Pp. 241-250 In: J. Alden, J.L. Mastrantonio and S. Ødum. (Eds.) Forest development in cold climates. Plenum Press, New York. Tikhomirov, B.A. 1959. The problem of the American-Asiatic floristic connections and the origin of the Soviet Arctic flora. Proceeding of the IX International Botanical (Congress 19-29 Aug. 1959) Montreal, Canada. Symposium: Alpigenous and arctogenous plants Prog. p. 121.

van Niejenhuis, A. and W.H. Parker, 1991. Adaptive variation among jack pine populations north of Lake Superior. Proc. 23rd C.T.I.A. Mtg., Ottawa, ON. 19-23 Aug. 1991. p. 27.

Viereck, L.A. and J.M. Foote. 1970. The status of Populus balsamifera and $P$. trichocarpa in Alaska. Canadian Field-Naturalist 84 (2): 169-173.

Viereck, L.A., C.T. Dyrness, K. Van Cleve and M.J. Foote 1983. Vegetation, soils and forest productivity in selected forest types in interior Alaska. Can. J. For. Res. 13: 703-720.

von Rudloff, E. and M.J. Holst. 1968. Chemosystematic studies in the genus Picea (Pinaceae). III The leaf oil of a Picea glauca $\mathrm{x}$ mariana hybrid (Rosendahl spruce). Can. J. Bot. 46: 1-4.

Wagner, D.B., Zhong-Xu Sun, R. Diddahally, R. Govindaraju and B.P. Dancik. 1990. Spatial patterns of chloroplast DNA and cone morphology viariation within populations of a Pinus banksiana $-P$. contorta sympatric region. Amer. Nat. 138: 156-170.

Wilkinson, R.C., J.W. Hanover, J.W. Wright and R.H. Flake. 1971. Genetic variation in the monoterpene composition of white spruce, For. Sci. 17: 83-90.

Winton, L.L. 1964. Meiosis and pollen release in white and black spruce and their hybrid. Minn. For. Notes No. 154, Sci. Jour. Ser. Pap. No. 5512. Univ. Minn. Agr. Exp. Sta.

Wolfe, J.A. and E.B. Leopold. 1967. Neogene and early Quaternary vegetation of northwestern North America and northeastern Asia. Pp. 193-206 In: D.M. Hopkins (Ed.). The Bering Land Bridge. Stanford Univ. Press, Stanford, CA.

Wright, J.W. 1955. Species crossability in spruce in relation to distribution and taxonomy. For. Sci. 1 (4): 319-349.

Yeatman, C.W. 1984. P.N.F.I. Genetics and breeding: Genetics of jack pine: 1982-1983. Proc. 19th C.T.I.A. Mtg., Toronto, ON. 22-26 Aug. 1983. p 138-140.

Yeh, F.C., W.C. Cheliak, B.P. Dancik, K. Illingworth, D.C. Trust and B.A. Pryhitka. 1985. Population differentiation in lodgepole pine, Pinus contorta ssp. latifolia: a discriminant analysis of allozyme variation. Can. J. Genet. Cytol. 27(2): 210-218.

Ying, C.C. 1984. Provenance research by the British Columbia Ministry of Forests, 1981-1983. Proc. 19th C.T.I.A. Mtg., Toronto, ON. 22-26 Aug. 1983. p. 207-209.

Zasada, J. and D. Grigal. 1978. The effects of silvicultural system and seed bed preparation on natural regeneration of white spruce and associated species. Proc. 5th North American For. Biol. Workshop. Hollis, C.A. and A.E. Squillace (Eds.). U.S.D.A. For. Serv. \& Soc. Amer. For., Gainsville, FL. p. 213-220.

Zuffa, L. 1975. A summary review of interspecific breeding in the genus Populus L. Proc. 14th C.T.I.A. Mtg., Frederiction, NB. 28-30 Aug. 1973. p. 107-123. 